\title{
Experience of Self-Efficacy Learning among Vocational Secondary School Students
}

\author{
Elod Gogh ${ }^{1}$, Reka Racsko ${ }^{1}$, Attila Kovari ${ }^{2,3}$ \\ ${ }^{1}$ Eszterházy Károly University, Eszterházy tér 1, 3300 Eger, Hungary, \\ elod.gogh@kossuth-csepel.hu; racsko.reka@uni-eszterhazy.hu \\ ${ }^{2}$ University of Dunaújváros, Institute of Engineering, Department of Natural \\ Science, Táncsics M. u. 1/a, 2400 Dunaújváros, Hungary, kovari@uniduna.hu \\ ${ }^{3}$ Óbuda University, Alba Regia Technical Faculty, Budai út 45, 8000 \\ Székesfehérvár, Hungary, kovari.attila@amk.uni-obuda.hu
}

\begin{abstract}
Self-study and self-efficacy are closely related concepts, and they are in connection even with lifelong learning. To develop real self-esteem in the learning process, it is important to be aware of one's abilities, weaknesses, and other characteristics that influence learning, which reinforces the foundations of learning motivation and lifelong learning. Self-efficacy and modern ICT solutions supporting self-directed learning become a more relevant role in self-learning outside the school context, i.e. in self-taught learning. This article examines self-efficacy in learning through a questionnaire survey for students at technical vocational secondary schools in Budapest $(N=1260)$ analyzing the answers to some of the self-efficacy statements based on the Motivated Strategies for Learning Questionnaire (MSLQ). The results can help develop modern ICT solutions that effectively support learning.
\end{abstract}

Keywords: self-efficacy; cognitive conditions; Motivated Strategies for Learning Questionnaire

\section{Introduction}

Cognitive conditions determine how effective an individual during the learning process is, namely how much time is needed for achieving new knowledge, and how quickly and what the person can acquire [1], [2]. Within this, there are three important factors. The first is prerequisite-knowledge, which is a kind of ability wherewith old knowledge can be connected with newly acquired knowledge. The result of the learning process is the change in the extant knowledge, in which basic knowledge is a priority because, without this, the expansion of the knowledge is not available [3]. Higher existing basic knowledge will produce better results, and students with less basic knowledge are dropping more and more behind. 
The second factor which is necessary to complete a learning activity requires a mental preparational level. The learning ability refers to the level of mental preparation required to complete a learning activity [4]. These include general abilities, like reading skills, but advanced abilities as well, like taking notes or sketching abilities. Knowledge and application of learning techniques, education methods, strategies are an important factor in the system of learning abilities [5] [38]. One of the most important learning abilities is metacognition, which is the knowledge about our knowledge, and the ability to direct it [6]-[7]. The third falls into the category of generic supplementary elements such as perception, memory, imagination, thinking concepts, which determine the learning process and its effectiveness [8]. The modern ICT possibilities effectively could support these findings using the advantages of VR and AR [9]-[12], cooperative methodologies together with gamification [13]-[16] and take the advantages of Cognitive Infocommunications and similar emerging technologies [17]-[19].

In the case of self-efficacy learning, it is difficult to make examinations without touching similar areas that are related to the learning process and to areas that influence the learning process. For example, in the case of self-regulated learning, both factors are linked to lifelong learning. In a narrower sense, the self-efficacy of learning is fundamentally dependent on the learning strategies of the individual involved in learning, which concept is currently a subject of many studies. Initially, approaches to learning strategies took place mainly in terms of information layout and processing approaches [20], later with metacognitive aspects [21] [22].

There are various ideas for grouping learning [23], but one of the most relevant and universal is Pintrich's study [24]. Research also addresses maladaptive learning strategies, which are strategies that inhibit success [25], among here can we rate, for example, looking for excuses or striving for perfectionism. These are most often observed when solving a given task exceeds the individuals' capabilities, successful completion of the task is unlikely, or when students feel threatened by their self-esteem [26]. Students attach different importance to learning, have different learning goals and are, therefore, differently satisfied with the quality of education, as well as their performance [27]. It is precisely these measures of student satisfaction, self-evaluations, and reflections that can help students improve their learning effectiveness, also the learning outcomes and, indirectly, lay the foundations for lifelong learning [28].

In this research, we are adapting previous works that examined motivational factors [7]. Of course, in Hungary, asking Hungarian students, the survey should be interpreted in the current education system and learning environment [39].

However, the reliability and validity of the questions should also be examined, which were done with the appropriate statistical methods after sampling, however, due to the length of the article, we cannot take advantage of the possibility of writing these in detail. 
In the case of training that takes place within the school context, such as by vocational secondary school training, a teacher can experience, that the effectiveness of the learning process on many students is often inefficient, so education itself is a great challenge for the teachers themselves, starting with creating the motivation [29]. Also, in the case of vocational secondary schools, the development of those competencies that are highly valued and prioritized by the labour market is of utmost importance [30]. Nowadays modern information and communication technologies (ICT) are of great importance in acquiring knowledge. These ICT tools provide the basis for even more effective lifelong learning, the most important of which is learning to be independent of time and place. Today, learning information, learning materials, explanations, and even the level of knowledge acquired can be accessed and controlled almost anywhere, anytime [31]. An important part of the ICT tools is knowledge assessment systems, which measure the cognitive performance of students. Problem-solving competences of students are nowadays thoroughly researched so those specific problem-solving strategies can be identified and reinforced amongst students [32]. The use of ICT tools attempts to support the school and independent learning, but this approach also has its difficulties [33]-[34]. Therefore, if the willingness to learn is given, but the learning strategy is inadequate, then there is time and energy invested into learning, but there are still no expected results. All this leads to increased anxiety and stress for the students, and later on, the desire to learn and the motivation diminish. These may be somewhat offset by virtual and electronic learning environments and systems that are better suited to the needs of the digital generation, and by atypical modern teaching methods [35]-[36].

The present research was based on earlier research [21]. The current study does not address learning strategies, but primarily examines self-efficacy factors in statements in such a way that the matching degree with them are summarized as results. Our research was carried out among students of vocational secondary schools of one of the vocational training centres in Budapest $(\mathrm{N}=1260)$. From the processing of the answers, we can conclude to what extent the learning-related factors of self-efficacy are present concerning the students. We believe that developing self-efficacy among students in our pedagogical work can also help in their endeavours in lifelong learning [37].

\section{Methodology}

The study aims to evaluate the self-efficacy of learning among students in a vocational secondary school in Budapest [21]. Because self-efficacious learning is an important factor in adult autonomous lifelong learning, therefore, the results obtained in the context of self-efficacy learning may lead to such conclusions, which support the pedagogical work as effectively as possible to make the learning process as effective as possible. 
The survey was carried out among students of 7 schools from a total of 13 member institutions of the Budapest Machinery Vocational Center (BGéSZC) by means of a voluntary questionnaire. The BGéSZC includes technical vocational secondary schools and thus reflects the institutional characteristics of vocational secondary schools and the characteristics of technical schools.

The member institutions were selected based on cooperative affinity based on prior requests. Due to incomplete member institution coverage and volunteering, the sample of students in schools is not complete, however, due to the sample number $(\mathrm{N}=1260)$, a hundred percent sampling would probably not have resulted in significantly different results. This assumption is also reinforced by the fact that the results of the institutional breakdown not included in the study due to their low relevance did not result in differences between schools.

The questionnaire contained several sets of questions, including self-regulatory questions based on the Motivated Strategies for Learning Questionnaire (MSLQ) (Pintrich and DeGroot, 1990). The questionnaires were completed on paper and the results were subsequently digitized. A total of 1260 evaluable questionnaires were completed in 81 classes. The statements in the questionnaire that examine student opinion are listed in Table 1.

Table 1

Learning self-efficacy statements based on MSLQ (Pintrich és DeGroot, 1990)

\begin{tabular}{lll}
\hline No & Question & Scale \\
\hline 1 & Compared with others in class I expect to do well. & $1-5$ \\
2 & Compared with the others in my class, I think I'm a good student. & $1-5$ \\
3 & $\begin{array}{l}\text { I think I will receive a good grade for this project compared with my } \\
\text { classmates. }\end{array}$ & $1-5$ \\
4 & I know I will be able to learn the material for this project. & $1-5$ \\
5 & Compared with my classmates I perform better. & $1-5$ \\
6 & Usually I'm certain I can understand the teacher's explanations. & $1-5$ \\
7 & I am sure I can do an excellent job on the problems and tasks assigned for & $1-5$ \\
& this project. & $1-5$ \\
8 & My study skills are better compared with others in this class. & $1-5$ \\
9 & Compared with other students in this class I think I know more about & \\
\hline
\end{tabular}

The questionnaire was filled in anonymously, and students could only be distinguished by their school, class, and gender. The scale used was a five-point Likert scale, with responses representing the degree of identification with a given statement. (1- never true for me, 2- sometimes true for me, 3- true for me about half the time, 4-frequently true for me, 5- always true for me).

In the questionnaire, questions related to learning self-efficacy were not declared directly for the topic, i.e. no questions were labeled, students encountered the statements only during the completion. Another important fact is that e.g. the 
self-efficacious learning statements did not follow one another but were mixed with other topics in the questionnaires to be completed.

\section{Results and Discussion}

Of the students enrolled in the survey, $93 \%$ are male and only $7 \%$ female, which of course reflects the gender distribution of the students in vocational secondary schools in the technical area. The rate can be explained by the fact that these types of vocational training are generally considered to be more popular with boys, - the same is the case for the participating students of the vocational secondary schools. The students gave 1260 answers, among them were 1168 boys and 92 girls. Of course, this ratio can be different for other types of (non-technical) vocational secondary schools. In vocational secondary schools, in general, the gender ratio is close to equal, with the proportion of boys being $52.8 \%$ (KSH, 2018).

The distribution of the students of each member institution of the Budapest Machinery Vocational Center is shown in Table 2. Due to data protection considerations, the actual names of the secondary schools are not listed in the table. That is, it is not our intention to draw conclusions about schools and compare them based on pupils specifically linked to schools.

Table 2

The sample numbers of the participating institutions

\begin{tabular}{|l|c|c|}
\hline $\begin{array}{c}\text { Vocational secondary } \\
\text { schools }\end{array}$ & Number of students & Number of classes \\
\hline Voc. secondary school 1 & 141 & 11 \\
\hline Voc. secondary school 2 & 191 & 10 \\
\hline Voc. secondary school 3 & 157 & 8 \\
\hline Voc. secondary school 4 & 209 & 12 \\
\hline Voc. secondary school 5 & 416 & 28 \\
\hline Voc. secondary school 6 & 52 & 6 \\
\hline Voc. secondary school 7 & 94 & 6 \\
\hline Total & $\mathbf{1 2 6 0}$ & $\mathbf{8 1}$ \\
\hline
\end{tabular}

The bar graph in Figure 1 shows that the number of students participating in research is significantly lower above the age of 25 , but it is important to look at the views of these students because they are already involved in adult education. So the participating students were mainly from the pre-baccalaureate (82\%), however, we also addressed students after mature vocational training courses. As the comparison of results by education training types did not result in significant differences, responses and results will be treated together later. 


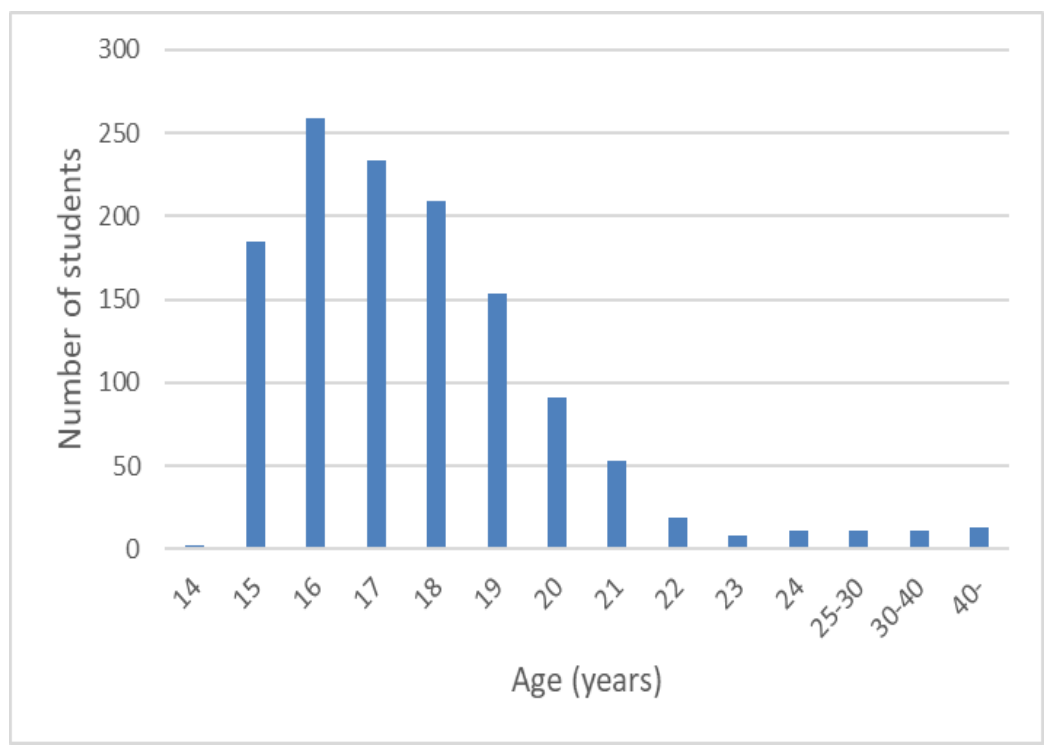

Figure 1

Distribution of research participating students by age

The study average of the respondents (based on the values described by the students, self-declaration), given to one decimal place, may be important for the research, the distribution of the data is shown in Figure 2.

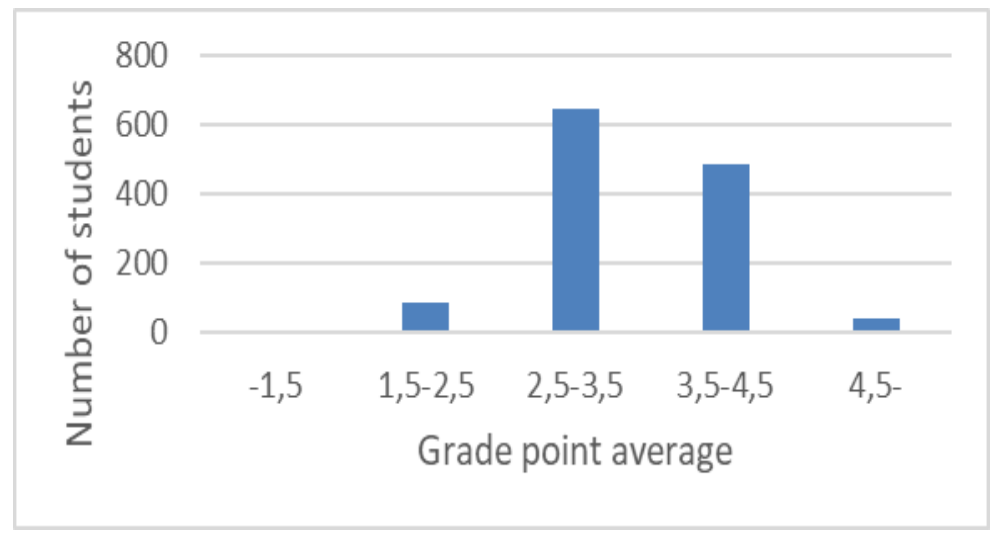

Figure 2

Distribution of study averages among students participating in research

Table 3 summarizes the relative frequencies of the answers to 9 questions related to learning self-efficacy. 
Table 3

Relative frequencies of answers to self-efficacy statements

\begin{tabular}{|c|l|c|c|c|c|c|}
\hline Nr. & \multicolumn{1}{|c|}{ Statement } & 1 & $\mathbf{2}$ & $\mathbf{3}$ & $\mathbf{4}$ & $\mathbf{5}$ \\
\hline 1 & $\begin{array}{l}\text { Compared with other students in this class I } \\
\text { expect to do well. }\end{array}$ & $11 \%$ & $27 \%$ & $\mathbf{2 8 \%}$ & $23 \%$ & $12 \%$ \\
\hline 2 & $\begin{array}{l}\text { Compared with the others in my class, I think } \\
\text { I'm a good student. }\end{array}$ & $14 \%$ & $33 \%$ & $24 \%$ & $20 \%$ & $9 \%$ \\
\hline 3 & $\begin{array}{l}\text { In my opinion I receive good grades compared } \\
\text { with my classmates. }\end{array}$ & $12 \%$ & $33 \%$ & $27 \%$ & $21 \%$ & $7 \%$ \\
\hline 4 & $\begin{array}{l}\text { I know I will be able to learn the material for this } \\
\text { project. }\end{array}$ & $2 \%$ & $11 \%$ & $27 \%$ & $35 \%$ & $24 \%$ \\
\hline 5 & $\begin{array}{l}\text { Compared with others in my class I usually do } \\
\text { better. }\end{array}$ & $11 \%$ & $39 \%$ & $26 \%$ & $18 \%$ & $6 \%$ \\
\hline 6 & $\begin{array}{l}\text { I'm certain I can understand the teacher } \\
\text { explanations related to the project work. }\end{array}$ & $3 \%$ & $20 \%$ & $35 \%$ & $33 \%$ & $8 \%$ \\
\hline 7 & $\begin{array}{l}\text { I am sure I can do an excellent job on the } \\
\text { problems and tasks assigned for this project. }\end{array}$ & $8 \%$ & $27 \%$ & $33 \%$ & $22 \%$ & $10 \%$ \\
\hline 8 & $\begin{array}{l}\text { My study skills are better compared with others } \\
\text { in this class. }\end{array}$ & $10 \%$ & $36 \%$ & $28 \%$ & $17 \%$ & $8 \%$ \\
\hline 9 & $\begin{array}{l}\text { Compared with other students in this class I } \\
\text { think I usually know more about some of the } \\
\text { subjects. }\end{array}$ & $6 \%$ & $35 \%$ & $25 \%$ & $27 \%$ & $7 \%$ \\
\hline
\end{tabular}

The frequency of the answers for each question is shown in the bar graphs in Figure 3-11. Based on the frequencies, a brief evaluation of each statement is summarized after each figure.

Each statement can be matched with a set of keywords resulting from the statements, which can be a subset of self-efficacy, respectively:

- $\quad$ self-expectation: comparing one's performance with the classmates'

- self-diligence: comparing one's diligence with the classmates'

- efficiency: positioning one's results and ordering in an imaginative row compared with the classmates'

- $\quad$ subject motivation based on one's abilities

- overall learning performance: comparing the overall performance with the classmates'

- classroom effectiveness and feedback about activity during the lesson

- comparing the performance of the community and cooperative work with the classmates'

- comparing learning abilities with the other students in the class

- comparing knowledge as a learning outcome with the classmates 
These individual concepts can also be grouped around the three factors (prerequisite knowledge, mental preparational level, general supplementary elements) related to self-effective learning described in the introduction that influences the effectiveness of the learning process. As self-effective learning belongs to the area related to motivation, the issues examined are mostly related to the topic of general supplementary elements. Of the learning theories, the humanistic learning theories discuss motivational factors the most.

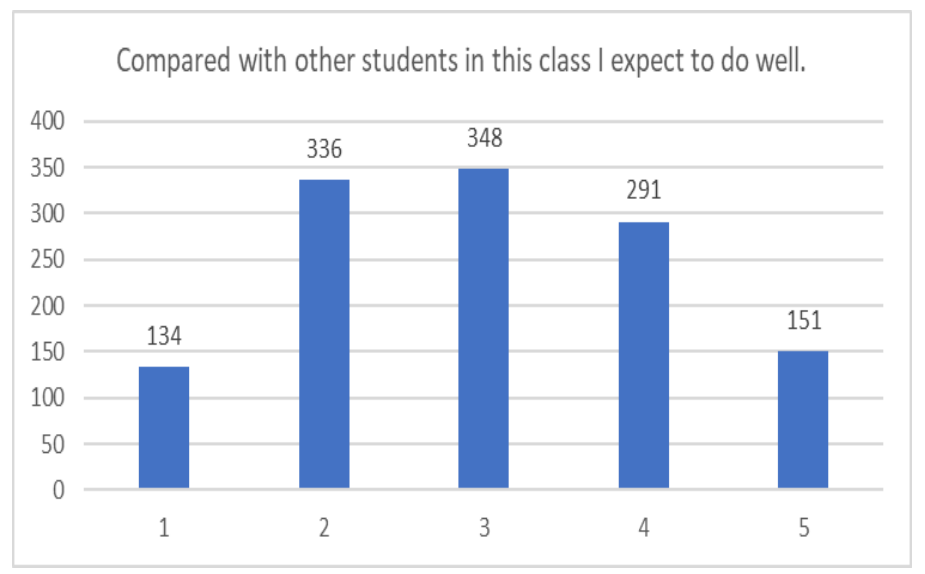

Figure 3

Distribution of frequency of answers to statement 1 of self-efficacy

The content of the statement involves two factors: one is self-expectation, it is based on the presence of an inner level, and the other is a comparison with classmates. The basis of comparison does not necessarily focus solely on knowledge but can include any school and learning aspects.

The distribution of the scale values of the responses is strikingly similar to the symmetric distribution, however, scale values 2 and 3 represent almost the same value and the value of 4 is almost double the distribution of the outer values of 1 and 5 .

The answers thus reflect that values 2, 3, and 4 are by far the most common. By reversing thinking, value 1 was probably given by almost completely unmotivated students, and the number 5 was probably considered too "geeky" by many.

The second statement also relates to comparisons with classmates. However, there is little sense in the underlying attribute of the word "more diligent", or the degree of diligence. It is simply about whether, by comparison, I can say that I am diligent or not. That is, whether the feature exists or not.

The distribution of scale values of 1 is relatively low, about half of the values of scale 2, which is by far the largest and accounts for a third of the answers. Subsequent scale values decrease almost linearly. 


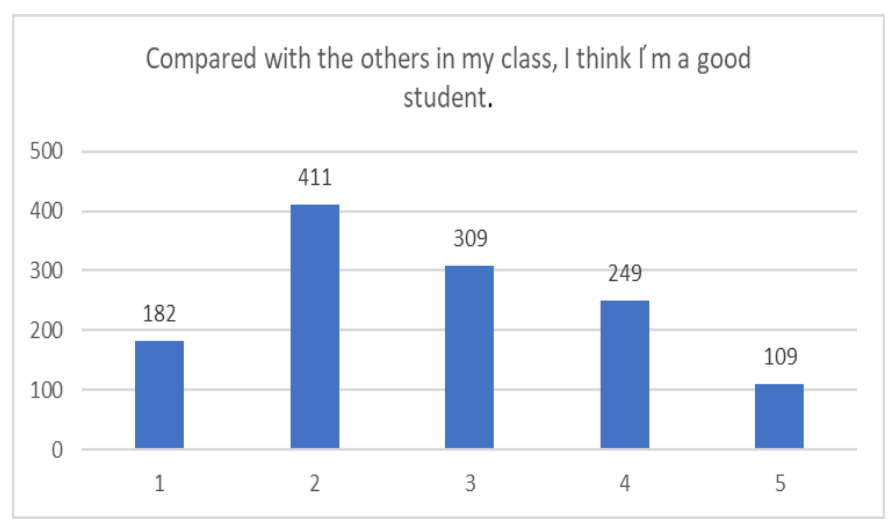

Figure 4

Distribution of frequency of answers to statement 2 of self-efficacy

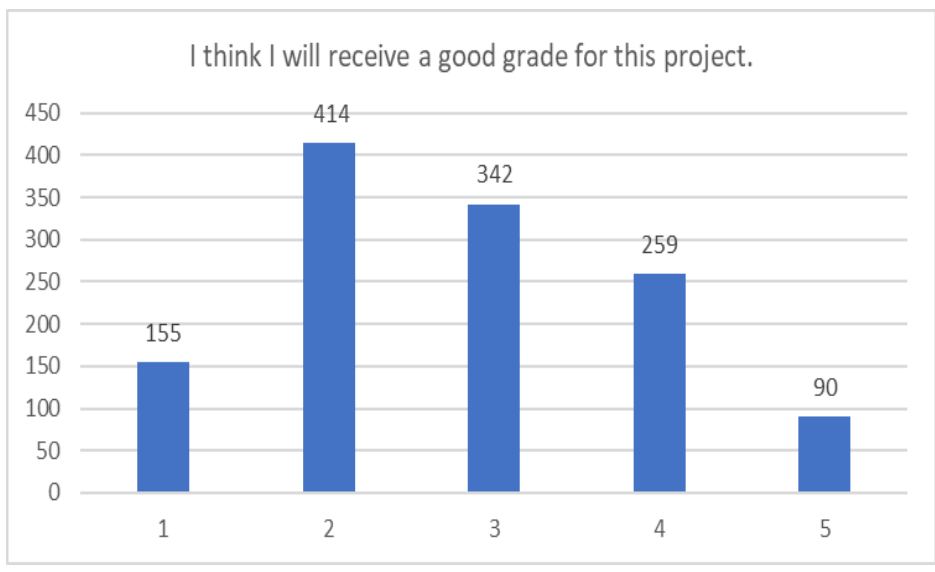

Figure 5

Distribution of frequency of answers to statement 3 of self-efficacy

This statement is also based on a comparison with a self-assessment in the background. In other words: based on the information available (since I obviously cannot know all the marks of all my classmates) do I get good grades, where do I place myself in this imaginary ranking? The statement is not considered further, but this statement can also be used to test the existence of student motivation.

The distributions of the answers are almost identical to the values given for the previous statement. It should be emphasized that in the original questionnaire the two statements did not follow one another, that is, the respondents did not automatically answer "set" to one response value. 


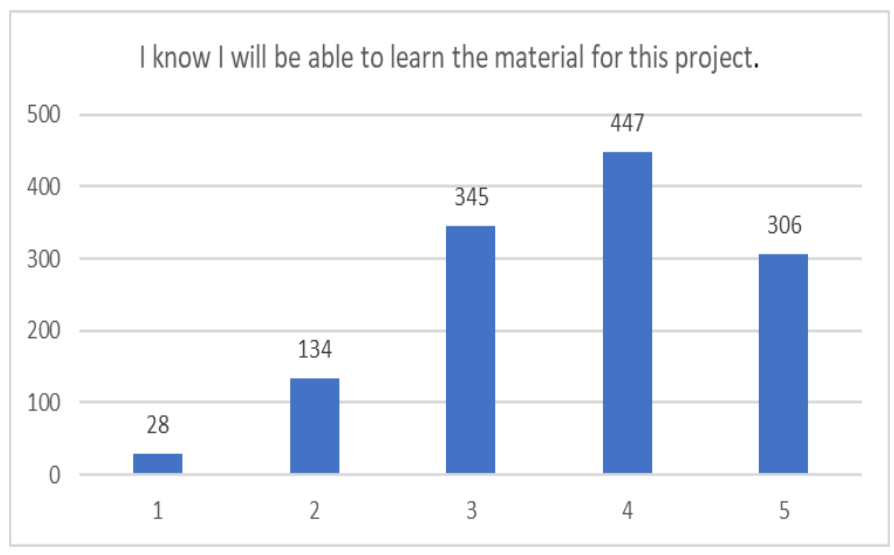

Figure 6

Distribution of frequency of answers to statement 4 of self-efficacy

The statement can also be related to motivation and self-esteem. It can also be related to self-efficacy because if the student approaches the curriculum with the promotion that it is impossible to learn because of many factors, on the one hand, will also find an excuse for not studying, on the other hand, reduces the effectiveness of learning to almost zero untimely.

If the student is aware of his/her abilities, the amount of time invested, the energy, and the proportionate expected results, in other words, its efficiency, and based on that, he/she knows that can meet expectations, it can have significant positive effects on the learning process: getting feedback on efficiency, motivation, time management, etc.

The distribution of responses increases steeply from a negligible value of 1 to the scale value of 4 , which accounts for more than a third of the answers. One-quarter of the answers were answered with a scale value of 5. That is, almost two-thirds of the respondents indicated values 4 and 5 .

Based on the results obtained, it can be assumed that students have significant self-confidence, they have a strong motivation level that can be relied upon during the pedagogical work.

The comparative nature of the statement is clear, but here the answers give no longer merely the presence or absence of the characteristic, such as. question 2 for diligence, but it must be clearly decided whether the respondent is better performing than his or her classmates in general or not. This "fulfillment" is not declared for a specific act but is meant generally.

The marked responses of the student values can be compared by the distribution of questions 2 and 3 . The bars in the chart are very similar in appearance, respectively. 


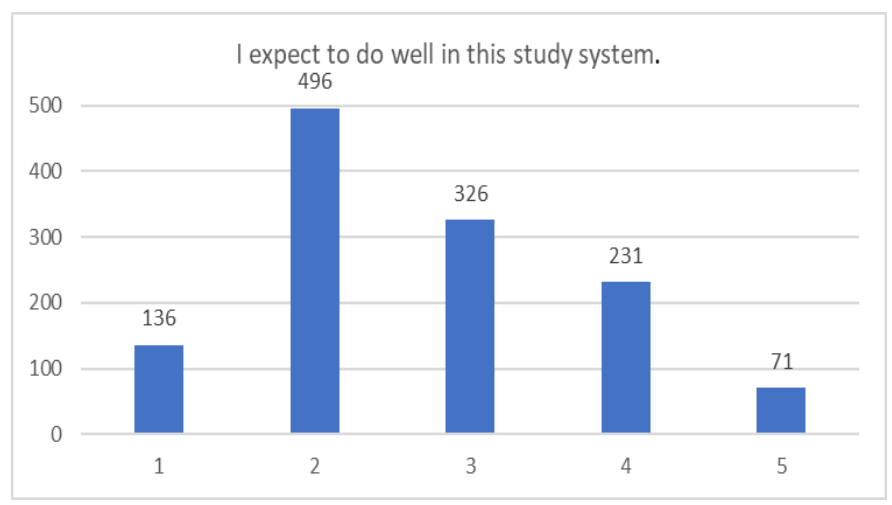

Figure 7

Distribution of frequency of answers to statement 5 of self-efficacy

More than a third of students answered with a value of 2 and a quarter of the participated students with a value of 3 .

Essentially, the statement provides feedback from the learner's perspective on classroom effectiveness. If the student can acquire the knowledge of the curriculum from both the teacher and the book, then the learning process is provided by two sources, and of course, this is a more effective way to acquire knowledge (assuming that the teacher does not read aloud from the book during the lesson; in all other cases, the two aspects are met). Any decrease from these two will impair the effectiveness of learning.

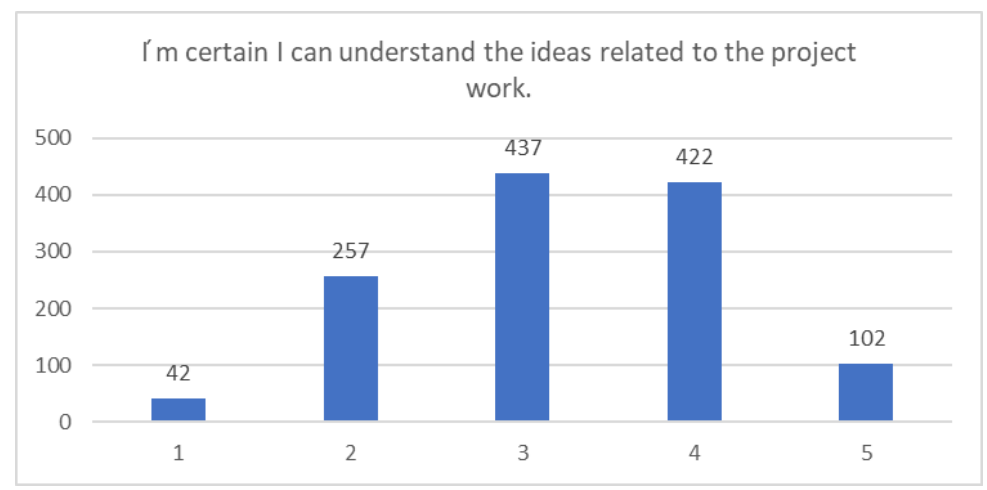

Figure 8

Distribution of frequency of answers to statement 6 of self-efficacy

In the answers, the distribution of the two external scale values is almost negligible compared to the other scale values. The highest values are 3 and 4 almost equally, which give the two-thirds coverage of the answers. The scale value 2 not mentioned above represents one-fifth of the answers. That is, the 
weight of the answers is above the average level of scale value 3, which is later confirmed numerically by the mean and standard deviation table, too. The results obtained can be said to be gratifying and this result can also be indirectly evaluated from the teacher's point of view as a measure of classroom effectiveness.

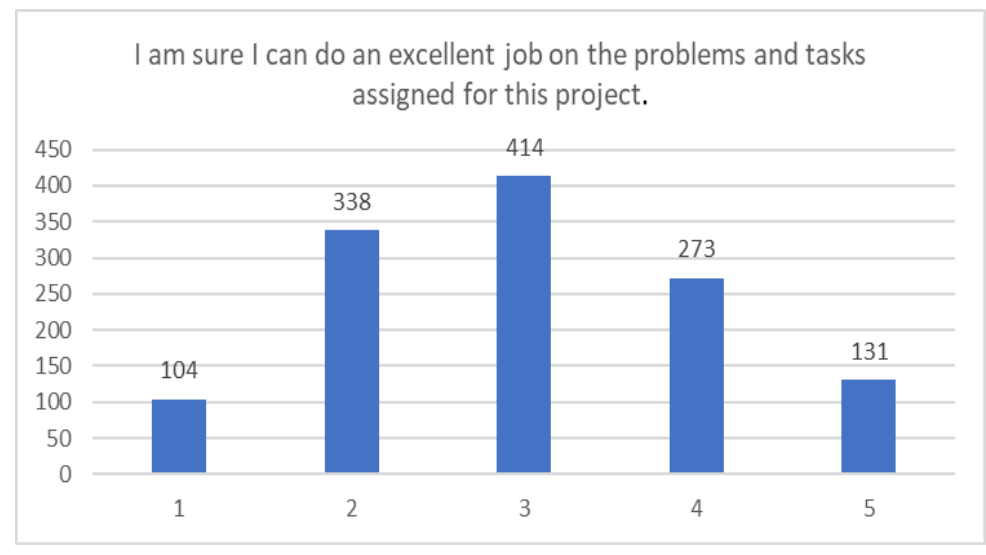

Figure 9

Distribution of frequency of answers to statement 7 of self-efficacy

The statement can be interpreted in several ways: on the one hand, based on a class community perspective, on the other hand, it also means the attitude of the students in cooperative learning or project assignments. We are talking about comparisons again and we can examine the basics of a community role.

The bar graph representation of the answers resembles the centre reflection of the answer distributions of statement 1 . The two external scale values show a small distribution, the middle scale 3 represents one-third of the answers, however, values 2 and 4 are not symmetrical, but symmetry is shifted towards value 2 . Accordingly, it can be stated that students identify with the statement in a completely average way.

A parallel can be drawn between statement and question 5. Here, too, as a responder, we can decide by comparison whether our abilities are better than those of our classmates'. Of course, learning abilities are not explained, they are only general, and we do not examine whether the answers are truthful or not. Learning abilities obviously affect the effectiveness of learning. These abilities can be developed and there are many techniques to improve them.

After examining statements 2, 3, and 5, the response values of statement 8 follow the same pattern and the same description can be repeated for the presentment of extremely similar distribution values. 


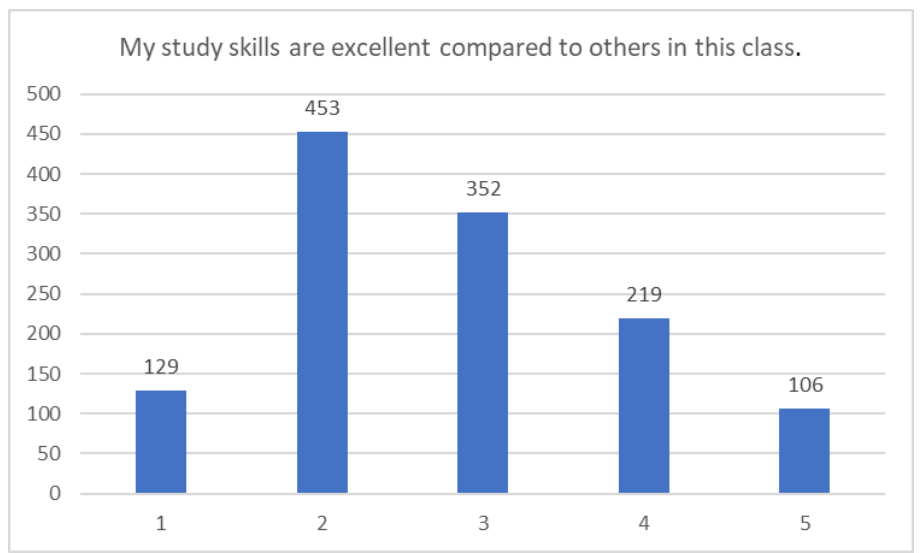

Figure 10

Distribution of frequency of answers to statement 8 of self-efficacy

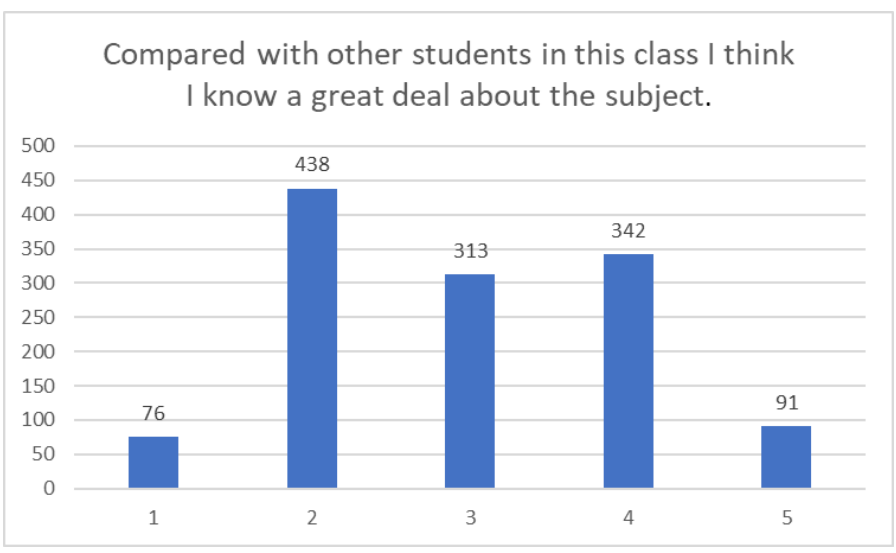

Figure 11

Distribution of frequency of answers to statement 9 of self-efficacy

The statement also includes in the background that I am better than the others, thus there is a decision in the comparison: am I better than average or not. At the same time, the statement does not examine the expense, the amount of energy invested, the path it takes, and the efficiency with which it compares the student with others, but focuses only on the actual outcome of the learning process.

Therefore, the statement is also a comparison and we would almost expect that the column values of the distribution values would produce similar results to the other statements $(2,3,5,8)$. This is true in a way, that the columns corresponding to the two external scale values are low (small distribution), and a scale value of 2 is the highest and also represents about a third of the answers. On the one hand, however, in this case, there is no "downturn" for the scale value of 4 . It represents 
the second-highest value with more than a quarter of the answers, the scale value 3 is almost exactly the same as the numerical quarter of the answers.

\section{Conclusions}

It can be read both in the statement-related keywords and in the statements themselves that many are based on a comparison with classmates' properties. Accordingly, prior to the evaluation, it could be predicted that there would be similar distributions for some statement.

Without any software evaluation, it can be stated that, statements 2, 3, 5, and 8 show very similar results. All of these involve some comparison, but not all such statements are equally distributed. In these cases, after a minor value of 1 , responses culminate on a scale value of 2 and they decrease almost linearly to the scale value of 5 . The reason for this is probably that the participated students for some reason have avoided the extreme level representing the value of 1 . A scale value of 2 indicates the answer is "sometimes true for me" and is related to students' self-esteem, that is, the values of 4 and 5 were largely felt to be exaggerated, which is why they were most likely responded with values of 2 and 3 , respectively.

In the case of statement 1 (Compared with other students in this class I expect to do well.), The answers show similar results to normal distribution.

In the case of statement 4 (I know I will be able to learn the material for this project.), we can consider the results as a right-shifted normal distribution with a maximum scale value of 4 .

Statement 6 (I' $\mathrm{m}$ certain I can understand the explanations related to the project work) is similarly related to students' self-confidence, however, the result values show something else, then as for statement 4 , it can be stated that a slightly better than average result can be realized (average of 3.23, second highest).

In the case of statement 7, a slightly distorted form of the normal distribution can be observed.

All in all, the evaluation with a statistic software confirmed the results described above, i.e. the deviations from the normal distribution:

- self-expectation: comparing own performance with the classmates';

- classroom effectiveness and feedback about activity during lessons.

These factors should be developed from a pedagogical point of view, they are not crucial areas.

Similar to Gaussian distribution, but the results are slightly worse by the following factors:

- comparing the performance of the community and cooperative work with the classmates'

- comparing knowledge as a learning outcome with the classmates' 
These factors provide a good basis for pedagogical work as in the previous category and do not require drastic pedagogical intervention.

The following, already discussed factors show a decreasing response-tendency after the scale value of two:

- self-diligence: comparing your own diligence with the classmates'

- efficiency: positioning one's results and ordering in an imaginative row compared with the classmates'

- learning overall performance: comparing the overall performance with the classmates'

- comparing learning abilities with the other students in the class

These factors require further pedagogical development.

First and foremost, actual performance needs to be taken in consideration in order to get a realistic picture and to exclude the distorting effect on responses that derive from lack of self-confidence. Based on these, the mentioned skills can be developed through the presentation and the awareness of learning strategies, which can deliver results in the medium and in the long term in terms of student success. We do not intend to make specific recommendations because of the scope of the study.

A good pedagogical factor can be the subject related motivation based on their own abilities, which shows that students have the needed self-confidence and they want to acquire knowledge.

Further analysis of the results and comparison with self-regulated learning may lead to further important findings. We plan to carry out these analyzes in the future.

The cognitive interpretation of the results, that is, the cognitive-centred approach, suggests that the self-efficacy form of acquiring knowledge is truly one of the highest levels of learning. Of the direct factors of cognitive ability, attention, and of the indirect factors, memory, are the most relevant to self-directed learning.

\section{Acknowledgement}

This research was supported by EFOP-3.6.1-16-2016-00003 grants, Establishment long-term R \& D \& I process at the University of Dunaujvaros. Also, thanks for the support of EFOP-3.6.2-16-2017-00018 „Produce together with the nature agroforestry as a new outbreaking possibility" project.

\section{References}

[1] Darling-Hammod L., et al.: Implications for educational practice of the science of learning and development. Applied Developmental Science, 2019, pp. 1-44 
[2] Grebenev I. V., Lozovskaya L. B.; Morozova E. O.: Methodology of determining student's cognitive styles and its application for teaching physics. SpringerPlus, Vol. 3, No. 1:449, 2014, pp. 1-8

[3] Fischer M., Sliwka D.: Confidence in knowledge or confidence in the ability to learn: An experiment on the causal effects of beliefs on motivation. Games and Economic Behavior, Vol. 111, 2018, pp. 122-142

[4] Schunk D. H.: Learning theories an educational perspective sixth edition. Pearson, 2012

[5] Kövecsesné Gősi V.: The pedagogical Project of Education for Sustainable Development in 3D virtual space. Proceedings of the $10^{\text {th }}$ IEEE International Conference on Cognitive, Naples, Italy, 2019, pp. 539-544

[6] Hartman H. J.: Developing students' metacognitive knowledge and skills. In: Metacognition in learning and instruction. Springer, Dordrecht, 2001, pp. 33-68

[7] Pintrich, P. R., De Groot, V.: Motivational and Self-Regulated Learning Components of Classroom Academic Performance. Journal of Educational Psychology, Vol. 82, No. 1, 1990, pp. 33-40

[8] Akdeniz C., et al.: Learning and Teaching: Theories, Approaches and Models. Ankara, Turkiye: Cozum, 2016

[9] Csapo A., Horvath I., Galambos P., Baranyi P.: VR as a Medium of Communication: from Memory Palaces to Comprehensive Memory Management, Proceedings of the $9^{\text {th }}$ IEEE International Conference on Cognitive Infocommunications, Budapest, 2018, pp. 389-394

[10] Guzsvinecz T., Kovacs Cs, Reich D., Szucs V., Sik-Lanyi C.: Developing a virtual reality application for the improvement of depth perception, $9^{\text {th }}$ IEEE International Conference on Cognitive Infocommunications, 2018, pp. 17-22

[11] Horvath I., Sudar A.: Factors contributing to the enhanced performance of the Maxwhere 3d VR platform in the distribution of digital information. Acta Polytechnica Hungarica, Vol. 15, No. 3, 2018, pp. 149-173

[12] Molnár G., Szüts, Z., Biró K.: Use of augmented reality in learning. Acta Polytechnica Hungarica, Vol. 15, No. 5, 2018, 209-222

[13] Orosz B., et al.: Digital education in digital cooperative environments. Journal of Applied Technical and Educational Sciences, Vol. 9, No. 4, 2019, pp. 55-69

[14] Jambor S.: Educational methods based on student activity in vocational education. Transactions on IT and Engineering Education, Vol. 2, No. 1, 2019, pp. 17-29 
[15] Horvath I.: MaxWhere 3D Capabilities Contributing to the Enhanced Efficiency of the Trello 2D Management Software. Acta Polytechnica Hungarica, Vol. 16, No. 6, 2019, pp. 55-71

[16] Sziládi G.: Applications of human-computer interfaces and related psychological-educational aspects. Computers \& Learning, Vol. 2, No. 1, 2019, pp. $1-14$

[17] Baranyi P., Csapo A., Sallai Gy.: Cognitive Infocommunications (CogInfoCom), Springer International Publishing Switzerland, 2015, p. 219

[18] Baranyi P., Csapó Á.: Definition and synergies of cognitive infocommunications. Acta Polytechnica Hungarica, Vol. 9, No. 1, 2012, pp. $67-83$

[19] Gilányi A., Chmielewska K.: Educational Context of Mathability. Acta Polytechnica Hungarica, Vol. 15, No. 5, 2018, pp. 223-237

[20] Entwistle, N. J., Ramsden, P.: Understanding student learning. London: Croom Helm. Entwistle, N., \& Tait, H.: Approaches to learning, evaluations of teaching, and preferences for contrasting academic environments. Higher Education, Vol. 19, No. 2, 1990, 169194

[21] Gogh, E., Kovari, A.: Experiences of Self-regulated Learning in a Vocational Secondary School. Journal of Applied Technical and Educational Sciences, Vol. 9, No. 2, 2019, 72-86

[22] Pintrich P. R.: A conceptual framework for assessing motivation and selfregulated learning in college students. Educational Psychology Review, Vol. 16, No. 4, 2004, pp. 385-407

[23] Hartwig M. K., Dunlosky J.: Study strategies of college students: Are selftesting and scheduling related to achievement?. Psychonomic Bulletin \& Review, Vol. 19, No. 1, 2012, pp. 126-134

[24] Pintrich P. R.: The role of motivation in promoting and sustaining selfregulated learning. International journal of educational research, Vol. 31, No. 6, 1999, pp. 459-470

[25] Urdan T., Midgley C.: Academic self-handicapping: What we know, what more there is to learn. Educational Psychology Review, Vol. 13, No. 2, 2001, pp. 115-138

[26] Nagy Z., D Molnar É.: Ineffective strategies and remedies to hinder learning (Tanulást hátráltató, nem hatékony stratégiák és korrigálási lehetőségeik). Magyar Pedagógia, Vol. 117, No. 4, 2017, pp. 347-363

[27] Ketonen E. E., Dietrich J., Moeller J., Salmela-Aro K., Lonka K.: The role of daily autonomous and controlled educational goals in students' academic emotion states: An experience sampling method approach. Learning and Instruction, Vol. 53, 2018, pp. 10-20 
[28] András I., Rajcsányi-Molnár M., Bacsa-Bán A., Balázs L., Németh I., Szabó Cs., Szalay Gy., Ardelean T.: Learning theories and the exploration of the peculiarities of the new generations based on learning outcomes (Tanuláselméletek és az új generációk sajátosságainak vizsgálata a tanulási eredmények alapján), Empirical studies in education within and outside of the borders (Empirikus kutatások az oktatásban határon innen és túl). Óbudai Egyetem Trefort Ágoston Mérnökpedagógiai Központ, Budapest, 2016, pp. 355-375

[29] Kálmán A. et al.: Issues of Lifelong Learning - Behavioral ends of teaching and learning through ICT, IEEE, Proceedings of the $9^{\text {th }}$ IEEE International Conference on Cognitive Infocommunications, Budapest, 2018, pp. 395398

[30] Rajcsányi-Molnár M. MaTech: Creative math competition for secondary school students assessing digital device usage (MaTech: Digitális eszközhasználaton alapuló kreatív matematika verseny szervezése középiskolás tanulóknak), Higher education innovations in the era of learning: challenges of digitalization, skill development and networking (Felsőoktatási innovációk a tanulás korában: a digitalizáció, képességfejlesztés és a hálózatosodás kihívásai) 2019, pp. 19-32

[31] Szenkovits B., et al.: Gamification and microcontent orientated methodological solutions based on bring-your-own device logic in higher education, IEEE, Proceedings of the $9^{\text {th }}$ IEEE International Conference on Cognitive Infocommunications, Budapest, 2018, pp. 385-388

[32] Pejić A., Stanić Molcer P.: Relationship Mining in PISA CBA 2012 Problem Solving Dataset using Association Rules, Proceedings of the $12^{\text {th }}$ International Symposium on Applied Computational Intelligence and Informatics, Timisoara, Romania, 2018, pp. 549-553

[33] Kővári A., Rajcsányi-Molnár M.: Mathability and Creative Problem Solving in the MaTech Math Competition, Acta Polytechnica Hungarica, Vol. 17, No. 2, 2020, pp. 147-161

[34] Ösz R., András I., Rajcsányi-Molnár M. Educational management questions of new generation smart phones: mobile generation in a changing learning environment - pedagogic challenges and paradigms ( $\mathrm{Az}$ újgenerációs mobil oktatásszervezés kérdései: A mobil generáció a változó tanulási környezetben - pedagógiai kihívások és paradigmák). Metamorphosis: Glocal Dilemmas in Three Acts (Metamorfózis: Glokális dilemmák három tételben) Új Mandátum Kiadó, Budapest, 2013, pp. 196215

[35] Námesztovszki Zs, et al.: Research of the usage of health-behavior improving mobile applications, Proceedings of the $10^{\text {th }}$ IEEE International Conference on Cognitive Infocommunications, Naples, 2019, pp. 619-624 
[36] András I., Rajcsányi-Molnár M., Bacsa-Bán A., Balázs L., Németh I., Szabó Cs., Szalay Gy. Reformation of methodologies in higher education: education technology approach in alliance with new teacher roles (Módszertani megújulás a felsőoktatásban: Az új oktatói szerepnek megfelelő oktatásmódszertani megközelítés). Dunakavics, Vol. 4, No. 6, 2016, pp. 25-62

[37] Kovari A.: Adult education 4.0 industry 4.0 challenges in lifelong learning, PedActa, Vol. 9, No. 1, 2019, pp. 9-16

[38] András Benedek et al.: Practices of Crowdsourcing in relation to Big Data Analysis and Education Methods, Proceedings of the $13^{\text {th }}$ International Symposium on Intelligent Systems and Informatics, 2015, pp. 167-172

[39] Zsolt Namestovski et al.: External Motivation, the Key to Success in the MOOCs Framework, Acta Polytechnica Hungarica, Vol. 15, No. 6, 2018, pp. $125-142$ 